\title{
Lincoln y Mora
}

Robert J. Lenzi, Asociación Abraham Lincoln

de los Estados Unidos de América

Recibido: 16/3/2015

Aceptado: 17/05/2015

"Vengo en nombre de la Asociación Abraham Lincoln para celebrar la grandeza de dos líderes nacionales, Juan Rafael Mora y Abraham Lincoln.

Aquí todos somos moristas, todos somos linconistas"

Robert J. Lenz. Lincoln y Mora. Revista Comunicación. Año 36, vol. 24, núm. 1. Enero - julio, 2015. Tecnológico de Costa Rica. ISSN Impreso: 0379-3974/ e-ISNN: 1659-3820

\section{LA ESCLAVITUD EN LOS ESTADOS UNIDOS}

En la época de la Revolución Americana, la esclavitud existía en las trece colonias. De 1777 a 1804, todos los Estados norteños dieron pasos para abolir la esclavitud, por lo general a través de una emancipación gradual. Estos fueron los primeros pasos legales hacia la emancipación en el Nuevo Mundo. A comienzos del siglo diecinueve, la esclavitud era la institución que diferenciaba a los estados sureños del resto de la Unión Americana.

\section{EL EXPANSIONISMO AMERICANO}

Cuando las trece colonias americanas vencieron a Inglaterra en la Guerra de Independencia, el nuevo gobierno adquirió inmediatamente la gran masa territorial al oeste de las montañas Allegheny, al norte del rio Ohio hasta el Misisipí y hacia el norte hasta el Canadá, conocido como el Territorio Noroeste. El estado de Illinois está ubicado en esta región y esa expansión más que duplicó la extensión geográfica del país.

Nuevamente se duplicó la extensión geográfica del país cuando el presidente Thomas Jefferson negoció con Napoleón la compra en 1803 del territorio de la Luisiana.

Ya en la década de 1840 la expansión se sustentaba, parcialmente, en la noción popular del destino manifiesto, como si la Providencia hubiera dispuesto que Estados Unidos ocupara todo el continente Norteamericano, sin importar los derechos de los Estados vecinos y de los pueblos originarios. Luego de la anexión de Texas, Estados Unidos declaró la guerra a México. Esta guerra gozó de amplio apoyo público en Estados Unidos, pero Abraham Lincoln, diputado por dos años en el Congreso Nacional, se opuso a la

i Robert Lenz es presidente de la Asociación Abraham Lincoln de los Estados Unidos de América. 
guerra. Al final del conflicto, el gobierno de México cedió el 40\% de su territorio a Estados Unidos por un precio nominal (incluido el actual estado de California).

Al mismo tiempo, el presidente Polk, alentado por los estados sureños, intentó comprar a España la Gran AntiIla, a fin de cumplir un sueño expansionista de añadir a Cuba como estado de la Unión Americana. Este fue un objetivo sureño de muchos años, en parte para expandir la esclavitud y en parte para sumar más curules en el Senado nacional. Estos acontecimientos, en particular la Guerra Mexicano-Americana, estimularon el crecimiento del filibusterismo por todo Latinoamérica desde 1848 hasta las vísperas de nuestra Guerra Civil.

Al concluir la Guerra Mexicano-Americana, la gran fiebre del oro en California hizo que miles de emigrantes de Estados Unidos fueran a California en busca de fortuna, cruzando el istmo centroamericano en las vecindades de Costa Rica, por Nicaragua y Panamá. En esos tiempos, creció la oposición en los Estados norteños a la expansión de la esclavitud en los Estados sureños. A mediados de la década de 1850, Abraham Lincoln emergió como el líder de un nuevo partido político en los Estados del oeste, partido que se organizó para atajar la expansión de la esclavitud. La opinión mayoritaria en los Estados norteños buscaba contener y, con el tiempo, extinguir la esclavitud. Este fue el conflicto que desembocó en la Guerra Civil de Estados Unidos.

\section{EL LIDERAZGO DE MORA CONTRA WILLIAM WALKER}

El Presidente Mora avizoró rápidamente la amenaza para Hispanoamérica cuando comprobó que William Walker y su ejército privado invadieron Nicaragua, aprovechándose de su guerra civil.

En mayo de 1855, Walker navegó hacia Centroamérica con un grupo de hombres armados. Unido a los demócratas en lucha contra los conservadores, a los pocos meses capturó Granada, derrotó a las fuerzas opositoras, y se convirtió en el virtual dictador del país, haciéndose llamar presidente tras unas elecciones fraudulentas. Durante su breve dictadura, legalizó la esclavitud y reabrió la trata de esclavos. El presidente Franklin Pierce concedió el reconocimiento diplomático de Estados Unidos al régimen de Walker. El objetivo intervencionista era la anexión para extender la esclavitud a Hispanoamérica y aumentar así el poder económico y político de los estados sureños. Expediciones similares, de otros aventureros, desembarcaron en México, Ecuador, Honduras y Cuba.
La historia de Juan Rafael Mora, es más conocida. En noviembre de 1855, el presidente de la República reconoció los peligros que representaban las fuerzas mercenarias de Walker y emitió una proclama a su pueblo. Convocó al Congreso Nacional para alertar sobre la amenaza filibustera. Llamó a las armas para preservar la independencia, la nacionalidad, la libertad y los derechos civiles de la nación. Bajo su liderazgo, el Gobierno formó un ejército y el parlamento autorizó justo a tiempo al Presidente Mora para marchar a la frontera y confrontar las fuerzas de Walker que ya habían cruzado la guardarraya e invadido el territorio de Costa Rica. El 20 de marzo de 1856, el ejército de Costa Rica ganó la Batalla de Santa Rosa. Un mes más tarde, Mora ganó la Batalla de Rivas. Fue el comienzo del fin de Walker.

Cuando Walker regresó a Estados Unidos, muchas ciudades sureñas lo recibieron como a un héroe. Cuando fue enjuiciado por violar las leyes de la Neutralidad, que prohíben a los ciudadanos hacer la guerra privada a otras naciones, un jurado sureño lo absolvió. Estos hechos demuestran que la opinión pública sureña favorecía fuertemente la expansión esclavista. Cuando Walker intentó una tercera invasión a Hispanoamérica, fue capturado por la armada británica por violar las leyes de la Neutralidad, siendo entregado a manos del gobierno de Honduras, donde encontró su fin el 12 de setiembre de 1860, menos de 60 días antes de que Lincoln fuera elegido Presidente de Estados Unidos.

\section{LA OPOSICIÓN DE LINCOLN AL FILIBUSTERISMO}

Permítanme relatarles qué sentía Abraham Lincoln sobre el filibusterismo en Hispanoamérica. Para empezar, se opuso a la guerra contra México. En el Congreso, Lincoln apoyó el Wilmot Proviso, proyecto de ley que prohibía la extensión de la esclavitud a los territorios adquiridos de México. La norma fue aprobada en la Cámara de Representantes pero no en el Senado, dominado por los sureños, donde imperó la oposición esclavista. Al ser electo presidente en 1861, una de sus primeras decisiones fue nombrar embajador en México a un ex senador del estado de Ohio, quien se había opuesto y votado contra la guerra. Al nombrar al senador Corwin, Lincoln notificó no solo a México sino a otras naciones también, su oposición al aventurerismo militar en el extranjero.

Tres años antes de que Walker desembarcara en Nicaragua, Lincoln pronunció un discurso en Springfield, Illinois, oponiéndose a la elección presidencial de Franklin Pierce. En ese discurso, 
Lincoln defendió la legalidad de la ejecución de 51 filibusteros que habían invadido a Cuba. Luego de renunciar toda autoridad o la protección del Gobierno de Estados Unidos, los filibusteros desembarcaron en Cuba. Fracasaron sus planes y fueron ejecutados por el gobierno cubano. Los partidarios de Pierce exigían satisfacciones, algunos insinuaron la necesidad de entrar en guerra contra Cuba. Lincoln respondió que en ausencia de un tratado, no había ningún derecho legal a interferir o exigir satisfacciones.

En 1857 Lincoln advirtió a los republicanos que si apoyaban al senador Stephen A. Douglas, el partido quedaría "uncido indefinidamente al filibusterismo favorecedor de los territorios esclavistas" y a la reactivación de la trata de esclavos africanos. Lincoln consideraba la esclavitud no solamente inmoral sino un "veneno mortal" para un gobierno que profesaba la igualdad del hombre.

Luego de la elección de Lincoln en 1860 y durante el periodo previo a la asunción del mando, varios estados sureños procuraron separarse de la Unión Americana porque sabían de su oposición al expansionismo esclavista. Numerosos republicanos pusilánimes pretendían en el Congreso evitar la secesión de esos Estados. Querían que los Estados esclavistas se reintegraran a la Unión Americana mediante un acuerdo de compromiso sobre el tema de la esclavitud. Lincoln escribió una serie de cartas las cuales muestran que él, al igual que Juan Rafael Mora, era un hombre de acero.

El 13 de diciembre de 1860, advirtió en una carta dirigida a un diputado que era imposible un acuerdo de compromiso sobre la expansión esclavista, porque tal compromiso traería aparejado el filibusterismo y la extensión de la esclavitud: "Sosténgase firme en el punto, como una cadena de acero".

A los pocos días, el 17 de diciembre de 1860, contestó una carta del líder político del estado de Nueva York quien propuso que todos los gobernadores norteños conferenciaran sobre un acuerdo que impidiera la separación de los estados sureños. De nuevo, Lincoln respondió que cualquier acuerdo de compromiso sobre la esclavitud daría pie al "filibusterismo en todas la tierras al sur de nosotros" Centroamérica incluida, transformadas a la larga en estados esclavistas.

Al día siguiente contestó una carta de otro líder político, quien atribuía mayor importancia que Lincoln a la amenaza del separatismo sureño, en términos seme- jantes a la idea de la conferencia de gobernadores en Nueva York.

Así como Mora peleó para evitar que la esclavitud se enseñoreara en su país, Lincoln peleó para evitar la expansión de la esclavitud, y aunque la aceptó, fue solo para terminar con la esclavitud y salvar a la Unión Americana; Mora iría a la guerra para prevenir la esclavitud y preservar la República de Costa Rica.

\section{IMÁGENES DE LINCOLN EN LATINOAMÉRICA}

Desde la época del Presidente Mora, creo ciertamente que Abraham Lincoln ha sido más admirado en Latinoamérica que en cualquier otra parte del mundo, excepto, claro, Estados Unidos. Muchas ciudades cuentan con una Escuela Lincoln, pero en San José hay dos: la Escuela Lincoln privada, que antes estuvo en Moravia y ahora está en barrio El Socorro, y la Escuela Lincoln en Alajuelita, que es una escuela pública y la segunda más antigua de Costa Rica. Hay pueblos en Cuba y en Argentina que llevan su nombre. Numerosos líderes políticos lo reclaman como "uno de los nuestros". Sarmiento se veía a sí mismo como el Lincoln argentino y hay referencias a Benito Juárez como el Lincoln mexicano. En Cuba se han trazado paralelos entre Lincoln y José Martí. Aquí y ahora me complace declarar que lo mismo puede afirmarse de Juan Rafael Mora. Además, desde setiembre de 2012, un retrato original de Juan Rafael Mora ocupa su sitio en la Galería de Patriotas Latinoamericanos de la Casa Rosada en Buenos Aires, Argentina. Por cierto, ese retrato fue realizado por el afamado artista costarricense Gonzalo Morales, quien también pintó el retrato de Abraham Lincoln que hemos develizado esta noche.

A lo largo y ancho de Latinoamérica se ve a Abraham Lincoln como un "constructor de la nación" porque él salvó a la Unión Americana. Es respetado por haberse elevado desde la pobreza, por su autodidaxia, además de su compasión por el hombre común. Lincoln es reconocido como defensor de los valores democráticos para todo el Hemisferio Occidental, un "americanista" auténtico. Las majestuosas palabras en su discurso de Gettysburg resuenan hoy para todos nosotros: "...que el gobierno del pueblo, por el pueblo, para el pueblo, no perecerá en la tierra". Él entendió que la Guerra Civil era una prueba para determinar si Estados Unidos "o cualquier nación así concebida" pudiese perdurar.

Lincoln no solo representa los valores de Estados Unidos, sino los ideales humanos más universales que también tienen aplicación en Latinoamérica. Para ser 
franco, debemos admitir hoy que la declaración de Theodore Roosevelt de ser el "policía de las Américas" fue un agudo contraste en comparación con el apoyo de Lincoln a la independencia nacional en Latinoamérica.

Un historiador cubano escribió sobre la actitud de cooperación interamericana de Lincoln. En este sentido, la reputación de Lincoln es bien merecida: fue el primer presidente de Estados Unidos que reconoció a Haití como república independiente; advirtió a España que el desembarco de sus tropas en Santo Domingo era un error; estableció buenas relaciones con Latinoamérica en general, pero especialmente con México.

Lincoln llegó a la presidencia después de varios presidentes expansionistas: el presidente Polk que inició la Guerra contra México, el presidente Pierce que alentó el filibusterismo y la campaña militar de William Walker en los años de 1850, y el presidente Buchanan que miró al otro lado cuando los poderes esclavistas buscaban expandir su influencia en Centroamérica. En contraste, Lincoln nombró diplomáticos respetuosos de Latinoamérica.

Abraham Lincoln articuló el nacionalismo de Estados Unidos para el mejoramiento de la humanidad y no solamente para que Estados Unidos avanzara.

Lincoln ha tenido muchos detractores, al igual que los ha tenido el Presidente Mora. Estos detractores sirven para recordarnos que los principios democráticos han sido fieramente disputados.

\section{LO QUE MORA IMPIDIÓ}

Al impedir la entrada de la esclavitud a Costa Rica, Juan Rafael Mora salvó a su país de la agonía, la hipocresía y la mancha de la esclavitud que infectó tan desfavorablemente a Estados Unidos y cuyos frutos amargos aún no han sido erradicados completamente en mi país.

No podemos subestimar lo que el Presidente Mora y sus heroicos seguidores lograron al derrotar a William Walker e impedir que la esclavitud fuese resta- blecida en Centroamérica. Ahora, uno no puede decir que una victoria de William Walker sobre Juan Rafael Mora hubiera causado que las mismas circunstancias imperaran en Costa Rica, Nicaragua y otras porciones de Centroamérica. Uno no puede decir que la esclavitud humana traída por los filibusteros hubiera durado tanto como perduró en Estados Unidos o en otros países del Hemisferio Occidental. Sin embargo, lo que uno sí puede decir con certeza y celebrarlo hoy es que la victoria de Costa Rica liderada por Juan Rafael Mora y su ejército contra William Walker y sobre la esclavitud, salvó a Costa Rica de los estados esclavistas.

\section{DOS HOMBRES EXTRAORDINARIOS}

Aunque los orígenes de Lincoln y de Mora son distintos, ambos fueron hombres hechos por ellos mismos, self-made men. Lincoln era abogado; Mora, comerciante y cafetalero. Fueron fieles a sus valores: Lincoln porque impidió la expansión de la esclavitud y fortaleció el imperio de la ley; Mora porque hizo bueno su juramento de proteger la soberanía de Costa Rica.

Ambos supieron construir coaliciones para alcanzar sus metas: Lincoln levantó un nuevo partido político en Illinois, que lo llevó a su elección; por vías diplomáticas, Mora forjó la cooperación centroamericana para expulsar a los filibusteros del expansionismo esclavista.

Uno y otro tuvieron una visión estratégica resultante en éxitos militares. Lincoln impuso un bloqueo naval de los puertos sureños y reorganizó el Ejercito de la Unión Americana; Mora dominó el río San Juan hasta impedir que Walker recibiera refuerzos y suministros en Nicaragua.

Ambos fueron varones de gran visión: Mora justipreció correctamente la amenaza que representaba Walker para la región; Lincoln resistió las demandas sureñas para negociar un acuerdo de compromiso sobre la expansión de la esclavitud.

En fin, ambos prohombres inspiraron a sus pueblos que siguieron sus liderazgos ante graves peligros para sus respectivos países. 